\title{
Content of double bonds in polyethylene
}

C Andrey O. Meshalkin, ${ }^{1+}$ Ulyana Yu. Tsyutskoma, ${ }^{1 *}$ Olesya I. Leonova, ${ }^{1}$ Fedor N. Bahov ${ }^{1}$ Lev V. Moskvitin, ${ }^{1}$ Mihail A. Arsentiev, ${ }^{1}$ Nikolay B. Berezin, ${ }^{2}$ and Zhanna V. Mezhevich ${ }^{2}$

${ }^{1}$ Department of Chemical Analysis. METACLAY Research and Development LLC. Bolshoy Bulvar St., 42, P.1. Territory of the SKOLKOVO Innovation Center. Moscow, 143026. Russia. Phone:+7 (499)969-81-30.E-mail: info@metaclay.com.

${ }^{2}$ Department of Technology of Electrochemical Production. Kazan National Research Technological University. K. Marx St., 68. Kazan, 420015. Republic of Tatarstan. Russia. Phone: +7 (843) 231-95-06.E-mail: berezintep@yandex.ru

\section{*Supervising author; ${ }^{+}$Corresponding author}

Keywords: double bonds, high-pressure polyethylene, calibration curves, molar adsorption, peak area.

The content of double bonds in high-pressure polyethylene of various brands obtained from Russian and foreign manufacturers was studied. The essence of the method was to build a calibration curve on an infrared Fourier spectrometer for standard substances with a previously known arrangement of the double bond, saturation of double bonds in the initial polyethylene using gaseous bromine, and subsequent assessment of the locations and number of double bonds in the studied brands of high pressure polyethylene. The calibration substances were trans-4-decene with a purity of $96 \%, 1$-decene with a purity of $95 \%$, and 2 methyl-1-heptene with a purity of $98 \%$. To record infrared spectra, calibration substances were dissolved in carbon disulfide with a purity of $99.5 \%$. The spectra of the calibration substances were recorded in the transmission mode. The recording of the spectra of the high-pressure polyethylene samples was carried out in the reflection mode. To calculate the molar adsorption coefficient of individual calibration substances, the areas of the peak absorption of individual substances were allocated. The Peak Separation NETZSCH software was used for this purpose. For all analyzed samples, both brominated and not brominated, the ratio of the areas of absorption peaks was calculated. For each sample of high-pressure polyethylene, the content of trans-vinylidene, vinyl, and vinylidene groups $\mathrm{C}=\mathrm{C}$ per 1000 carbon atoms was determined. The total number of double bonds was calculated as the sum of all analyzed bonds contained in the polyethylene sample. The accuracy of the analysis method performed by a single laboratory on a single sample is $\pm 10 \%$ of double bonds per 1000 carbon atoms. The technique allows one to evaluate such a characteristic of low density polyethylene as the content of double bonds. This characteristic is essential for the efficient development of crosslinkable polyethylene compounds.

\section{References}

[1] N.M. Zinger, V.G. Bestolchenko, A.A. Zhidkov. Improving the efficiency of thermal points. Moscow: Stroizdat. 1990. 185 p. (russian)

[2] Taschenbuch fur Heizung + Klimatechnik. 97/98.

[3] ASHRAE Standard 62-1999. Ventilation for Acceptable Indoor Quality.

[4] S.N. Ermakov, M.L. Kerber, T.P. Kravchenko, D.Yu. Shitov, V.A. Kostina, I.Yu. Gorbunova. Chemical reactions of polymers. Some of the principles of modern classification. Plastic. 2014. No.1-2. P.10-18. (russian)

[5] V.F. Gershkovich. Mold on the walls. The German lesson. Heat supply news. 2002. No.1. P.51. (russian)

[6] E.Ya. Sokolov. Teplofikatsiya I teplovye SETI. Moscow: Izd-vo MEI. 2001. 472p. (russian)

[7] S.A. Chistovich. Concept of development of district heating systems. Teploenergoeffektivnye tekhnol.: inform. bul. (Saint-Petersburg). 2002. No.3(29). (russian)

[8] S.V. Pivovarov, F.R. Garieva, N.V. lyzhina. Modernization of high-pressure polyethylene production. Vestnik Tehnolog. University. 2017. Vol.20. No.12. P.67-68. (russian)

[9] ASTM D3124-98 (re-approved in 2011). Standard method for determining vinylidene unsaturation in polyethylene by infrared spectroscopy.

[10] Jr.J.A. Anderson, V.D. Seyfried. Determination of oxygen and olefin compounds by infrared spectroscopy. Analytical chemistry. 1948. Vol.20. P.998-1006. (russian)

[11] Patent. Polymer composition with a delayed cross-linking process EP 1'695'996 A1.

[12] V.A. Kiesel, V.S. Osipchik, E.D. Lebedeva. Comparative analysis of the structure and properties of cross-linked polyethylene by various methods. Plastics. 2005. No.8. P.3-6. (russian) 